\title{
The Emergence of Systemic Risk:
}

\section{Federal Reserve, Bailouts, and Monetary Government at the Limits Onur Özgöde ${ }^{1}$}

\begin{abstract}
Why does the Federal Reserve govern finance in violation of a core principle of political liberalism, private risk-private loss? To solve this puzzle, this paper examines the emergence of systemic risk and its management by the Fed since 1951. Using Fed publications, interviews with officials, and transcripts of congressional hearings, it argues that systemic risk is a pathology of the monetary government of the economy. As such, systemic risk is at once the effect of the overflow of the financial architecture through which the Fed governs and a discursive object that purifies not only this overflow but also the breaches the Fed's emergency management strategies cause in the state-economy boundary. By turning regulatory capture theory on its head, the paper shows that the Fed put itself in such a politico-economically precarious position in managing financial emergencies because it is captured not by financial interests, but by systemic risk.
\end{abstract}

Keywords: Economic sociology, financialization, financial crisis, risk, neo-liberalism, monetary policy

JEL classification: Z1: Economic Sociology, E5 Monetary Policy, Central Banking, and the Supply of Money and Credit, G280 Financial Institutions and Services: Government Policy and Regulation

\section{Acknowledgments:}

I would like to thank Benjamin Braun, Stephen Collier, Alperen Evrin, Gil Eyal, Sheila Jasanoff, Paul Kershaw, Timothy Mitchell, Antti Silvast, and Alden Young for their contributions.

\footnotetext{
${ }^{1}$ Northwestern University; Department of Sociology, 1810 Chicago Avenue, Evanston, IL 60208; (646) 522-1279; oo2002@columbia.edu
} 


\section{Introduction}

At a 1991 congressional hearing on bank bailouts, Fed governor John LaWare emphasized the importance of managing systemic risk. He pleaded that Congress maintain the Fed's discretionary authority to provide emergency funds to financial institutions whose failure could cause the financial system to collapse. Likening an international bank's disorderly default to the Chernobyl nuclear disaster, he warned that the destabilizing impact would spread with "such lighting speed" and "so broad[ly]" that they would be impossible to control. This would pose "the risk of bringing down other banks, corporations, disrupting markets, bringing down investment banks," and "disrupt[ing] the whole system." It was imperative for the Fed to keep such firms afloat until their failure was no longer a threat (Economic Implications, 1991, p. 34).

Mitigating systemic risk, however, poses a serious threat to the Fed's autonomy, because it goes against a core principle of political liberalism - private risk-private loss. According to this principle, firms should succeed or fail solely by dint of market forces; if private enterprises are entitled to enjoy their profits, they should also suffer the pain of their losses. Monetarists (Friedman, 1974; Schwartz, 1992; Meltzer, 2010) argue "bailouts" undermine market discipline and cause "moral hazards," resulting in even more bailouts. Similarly, capture theorists (Stiglitz, 2010; Johnson and Kwak, 2010; Kwak, 2013) claim the Fed is captured by financial interests. Pointing to the "revolving door" between the Fed and Wall Street, they dismiss "systemic risk" as a smokescreen for the socialization of losses and blame the Fed for turning a blind eye to excessive risk-taking. Critics of systemic risk, thus, reduce systemic risk to a "social construct" that masks "real" problems, a label behind which hides the fact that the state and the Fed have been captured by big banks.

Economic sociologists, in contrast, rightly underscore the role that systemic risk played in the global financial crisis of 2008. They, however, conceive it either as a sui generis property of the financial system (Centeno et al., 2015) or as a "real" outcome (MacKenzie and Millo, 2003; Muniesa, 2015; Langley, 2016). ${ }^{1}$ Like capture theorists, these scholars assume systemic risk to

\footnotetext{
${ }^{1}$ Also see pieces by Mitchell Abolafia, Frank Dobbin and Jiwook Jung, and Richard Swedberg in the volume on the crisis (Lounsbury and Hirsch, 2010).
} 


\section{Capture Theory}
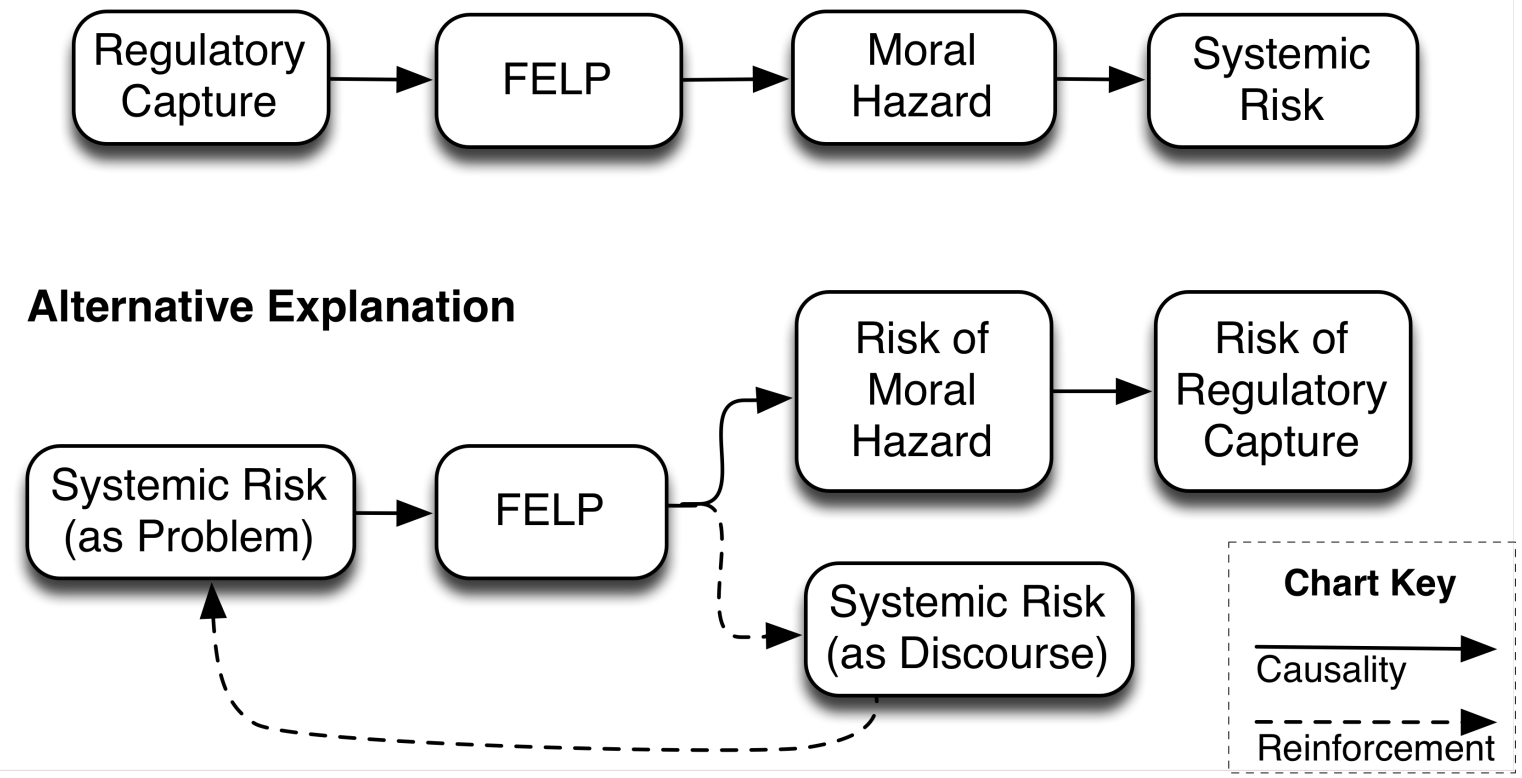

Figure 1: Two Paths of Systemic Risk

be a new problem. Their failure to historicize this concept leads them to conceptualize it as a market phenomenon and ignore the Fed's role in its emergence. In short, all three literatures overlook the puzzle of why in managing systemic risk the Fed puts itself in such a politicoeconomically precarious position.

To solve this puzzle, I turn capture theory on its head and argue that the Fed has been captured not by financial interests, but by the systemic risk discourse. Using Michel Callon's (1998a) analytics of framing and overflows within a Foucaultian perspective, I argue that systemic risk is a historically specific pathology of monetary government that is foundational to the way in which the Fed governs the economy. It is at once the effect of the overflow of the financial and monetary architectures through which the Fed governs and a discursive object at the heart of the emergency management practices designed to purify not only this overflow but also the breaches these practices cause in the state-economy boundary. Thus, systemic risk is a product of the same financial restructuring that it is meant to describe. It only exists as a function of the money market through which the Fed to governs the economy, and only as a function of the fact that the boundary between the state and banks is blurred and "thickened" in these 
markets. As Figure 1 illustrates, systemic risk discourse has been shaping the Fed's actions since the 1960 s, because "systemic risk," as a discursive object, allows the Fed to protect the money market as a key component of the "monetary policy transmission mechanism" through which the Fed manages economic growth. The Fed's response to the 2008 crisis, therefore, was conditioned by its understanding of systemic risk, because the response was constrained by the institutionalized rules of formation (Foucault, 1972) under which the Fed came to conceive, represent, and intervene in systemic risk, which was itself internally related to the system in crisis from the very beginning.

In its material foundations, systemic risk is an overflow of a new financial ontology of interdependence that formed in the short-term segments of the money market in the 1960s. This structure was built out of money market instruments, particularly federal funds (ff) loans and negotiable certificates of interests (CDs). This development was caused by a group of actors that I call "monetary substantivists"-monetary, because they were trained in monetary economics, and substantivist, because they believed in a way of governing that, similar to Marx's theory of use-value and crisis, took seriously the substantive properties of financial assets and therefore targeted intra-firm investment practices. Controlling the Fed between 1951 and 1970, substantivists deployed the Fed as a risk suppression apparatus. The more the Fed squeezed bank lending, the more the banks became entangled in money markets. Systemic risk, thus, was born as a provoked reality (Muniesa, 2015) in 1966 when the Fed caused a liquidity crunch in money markets.

While this trial of explicitness (Ibid., pp. 24-26) was the necessary condition for the emergence of systemic risk, it was insufficient for its intelligibility (as an economic problem) and its stabilization (as a governmental concept). What was needed were policy entrepreneurs who could problematize systemic risk as an economic phenomenon and then reconstruct it as a techno-political problem that could be managed. I call these actors "monetary nominalists," because they were also trained in monetary economics, but, unlike substantivists, they preferred to bracket the substantive qualities of intra-firm investment practices vis-à-vis specific assets and instead governed at the scale of aggregate nominal price level.

Nominalists sought to make the Fed the central locus of macroeconomic governance. For the Fed to manage growth, however, the financial sector had to function as a policy 
infrastructure. This required the Fed to govern through open market operations (OMOs) in the ff market - the core money market. Money markets, therefore, not only had to be protected from a liquidity crunch at all costs but also had to be nurtured, because growth depended on short-term credit generated by them. To achieve both goals, nominalists established the Financial Emergency Lending Program (FELP) in 1970. Reframing the overflows in money market instruments as bank failures, FELP mitigated liquidity crunches by averting bank collapses. FELP, however, did not simply protect these markets; it also performed them. Nominalists thus constructed systemic risk as an inherent property of the architecture of monetary governance.

In this new architecture, the financial system was transformed into a policy infrastructure - a hybrid entity (Latour, 1993) that was part of both the economy and the state. Consequently, "systemic risk," as a discursive object, was invented in the early 1980s by an emergent systemic faction within nominalism to purify (Douglas, 2002) the system's hybridity. These actors reproblematized systemic risk as a systemic vulnerability inherent to the new financial architecture. Mitigating systemic risk, therefore, was not enough to restore the Fed's decaying autonomy against congress and markets. The system's vulnerability also had to be reduced.

The systemic approach allowed the Fed to disentangle itself from financial and political interests in two ways. On the financial front, vulnerability reduction reinforced the stateeconomy boundary (Mitchell, 1991) and thereby freed the Fed from a structural double bind that forced it to make an impossible choice between underwriting the entire system's risks and letting it collapse. On the political front, nominalists deployed "systemic risk" as a boundary object (Star and Griesemer, 1989) against a congress infuriated by bailouts to disentangle public concerns of system-security from private matters of profit. In short, systemic risk purified the architecture of monetary governance from the profanity of bailouts. Thereby, it allowed the Fed to maintain its autonomy while continuing to manage the financial system, and systemic risk, at a distance (Miller and Rose, 1990), without suppressing short-term credit.

This paper extends performativity theory to the state and examines how economics coproduces the state and the economy (Callon, 1998a). Although Callon (1998b, pp. 40-42) pointed to the state as a critical dimension of performativity, performativity scholars did not 
explore it. Following Marion Fourcade's invitation (2007) to see performativity as a "rejoinder to neofoucaulitian tradition," I contend that state apparatuses (dispositifs) (Foucault, 1977) provide an alternative route for performativity. The formation of this channel, through the construction of governmental problems such as systemic risk, not only governmentalizes the state (Foucault, 2007), but also reproduces marketized relations such as finance.

Following Foucault, I call this detour "securitification." As a complementary economization mode to marketization (Çalışkan and Callon, 2009), securitification occurs through reiterative problem-solving processes (Hall, 1993; Haydu, 1998) in which policy entrepreneurs problematize emergent socio-economic concerns into stable and intelligible governmental problems and assemble apparatuses to manage them. From this perspective, financialization of the economy (Krippner, 2005; Davis, 2009) can be construed as unintended outcome of the deliberate construction of a short-term credit circuit-generated by the money market-by policy entrepreneurs to reinvigorate growth as a solution to the nation's mounting socio-political problems. Based on this pragmatic perspective, this paper, by focusing on the formation of a prototypically "neoliberal" problem ("too big to fail" vis-a-vis systemic risk) at one of the epicenters of "neoliberalism" (the Fed), joins the scholars (Bockman and Eyal, 2002; Fourcade-Gourinchas and Babb, 2002; Prasad, 2006; Krippner, 2011) who study what Krippner (2007) calls the pragmatic "route to neoliberalism." As the paper shows, despite being closely identified with "neoliberalism," bank bailouts have their genealogical roots in a governmental plane that developed contra neoliberalism a la monetarism. As Gil Eyal (2000; 2003) also suggests, understanding the evolution of the co-constitutive relationship between the state and the economy (Block, 1994) requires us to examine the implementation of concrete technopolitical governmental projects in specific state institutions by specific actors against specific problems.

\section{Emergence of Systemic Risk}

Systemic risk's material foundations were laid in the money markets of the 1960s. These markets had dried up after the Great Depression when banks became so risk averse that they held more US Treasuries than loans. After the 1951 Treasury-Fed Accord as the Fed transitioned to an 
independent monetary policy, the tide turned. Treasuries became riskier, and banks faced a booming yet inflationary economic environment that punished risk aversion. They responded to increasing credit demand by replacing Treasuries with higher return loans, which forced them to seek liquid assets to finance lending. In the absence of a deep money market, large banks (henceforth "banks") turned to the discount window, pushing daily average transactions to a record level of \$1.5 billion (FRB, 1968, pp. 3-4; Cook and LaRoche, 1993, p. 30).

Substantivists, led by the new Fed chairman William Martin, were alarmed by this new reality, which was unseen since the Great Depression. Subscribing to the real bills doctrine, these actors distinguished between "productive" and "speculative" credit and pursued a countercyclical credit policy "to lean against the wind" of excessive credit as a precaution against depressions (Bremner, 2004). Rather than using the Fed's "prompt corrective action" authority to roll back lending, they deployed credit control tools to exert abrasive pressure on the banking system. Substantivists preferred those instruments - reserve requirements, interest rate ceilings on CDs (Regulation Q), and the discount window-because the Fed governs within a liberal politicolegal ontology that co-constitutes the Fed and member banks as relatively autonomous entities. Banks' voluntary membership in the Federal Reserve System forces the Fed to approach governing as a matter of proactive and yet measured conduct of conduct (Foucault 2007).

Substantivism's limits were first tested in the mid-1950s when substantivists, worrying that the discount window was encouraging excessive risk-taking, began to ration window lending in 1955. In reaction, banks rediscovered the money markets, particularly the ff market. This market had already more than doubled up to a daily average of $\$ 800$ million since 1951 and would reach $\$ 3.5$ billion by 1966 (Willis, 1970). Remarkably, this explosive growth happened despite the Fed's "active restraint" policies, which forced monetary control devices to their limits so much that it caused disintermediation in 1959 (Bremner, 2004).

The decisive rupture in the Fed's relationship to banks occurred when banks innovated their way out of the Fed's reach in the 1960s. Shaken by the Fed's unpredictable actions, including the discount window reform, the First National City Bank of New York (now Citibank) introduced a new money market instrument, CDs, in 1961. By 1966, CDs became the money market's third largest segment after ffs and Treasuries (see Figure 2; Willis, 1970). As 
Edward Ettin, a Fed economist who took part in the establishment of FELP as then the chief of Capital Markets Section of the Research Division, put it, CDs were a "fascinating [innovation that] led [to] institutions rely more on markets for liquidity" (Ettin, interview, March 8, 2018).

As a market device (Muniesa et al., 2007), CDs reframed the fickle relationship between banks and depositors. By fixing maturity to a specific time horizon, they eliminated the withdrawal risk and thereby disentangled banks from depositors until maturity. Mimicking Treasuries' properties such as fixed maturity and return and a liquid secondary market, CDs transformed a dormant saving device (time deposits) into a liquid, efficient, and safe debt instrument. Their large denominations (over $\$ 100$ thousand) enabled banks to deal directly with large corporations and investors. Banks could now circumvent the geographic branching restrictions that substantivists imposed on them under the 1933 Glass-Steagall Act. The ability to raise funds from anywhere, whenever they needed liquidity, allowed banks to function universally and leverage with a near-unlimited borrowing power (Wojnilower, 1980, pp. 284$85)$.

Although CDs enhanced banks' autonomy, they also created new interdependencies. In Ettin's words, these devices "certainly made systemic risk a more reasonable thing to expect to occur," as they "intensified it" (Ettin, interview). Banks, already interlinked through the ff market, became further interconnected, since a loss of confidence in one institution could spread to others in this market. Furthermore, CDs radically transformed banks' structural position within the banking system, making them a liquidity source for regional and rural banks and thereby linking parts of the banking system that had been firewalled by Glass-Steagall. Thus, idiosyncratic risks of previously unconnected financial institutions' became interlinked, piercing through Glass-Steagall's firewalls long before derivatives would in the 1980s (Funk and Hirschman, 2014).

Substantivism was tested again in 1966, producing the first trial of explicitness for systemic risk: a credit crunch that revealed the implosive properties of the increasing financial interdependence. In contrast to future trials, this crisis was provoked by the Fed. In the summer 
$300.00 \%$

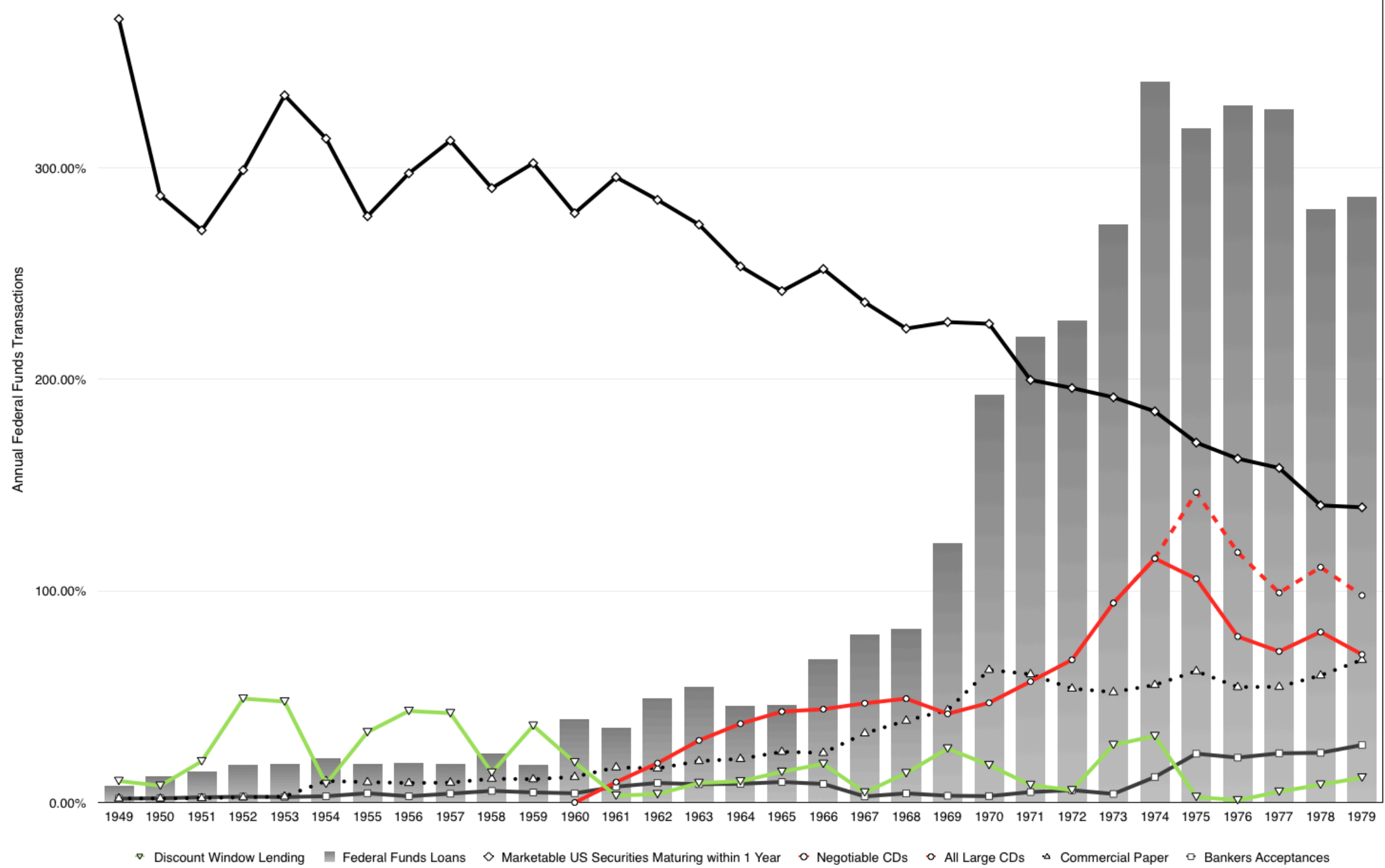

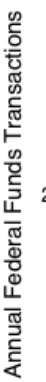


of 1966, after Congress failed to pass an anti-inflationary tax hike, the Fed squeezed bank liquidity from all directions - lowering $\mathrm{CD}$ interest rate ceilings, increasing reserve requirements, and rationing discount window lending. Bankers, already anxious about rolling over maturing CDs, scrambled for liquidity. The CD market contracted, and the economy entered a recession (Wojnilower, 1980, p. 288).

The liquidity crunch ended the substantivists' reign, as the Fed abandoned credit control tools, most notably reserve requirements and Regulation Q. The crisis also convinced Nixon to replace Chairman Martin with Arthur Burns, a leading nominalist. The nominalists' victory was symbolized in the Fed's public and private reassurances that such a crisis would be never repeated. In addition, the crunch caused banks to discover the Eurodollar market in London as a new liquidity source. In this global market, completely outside the Fed's jurisdiction, banks could raise CDs at much lower costs and circumvent the Fed (Wojnilower, 1980; Bremner, 2004).

In short, by provoking a crunch the Fed did not simply make a pre-existing reality explicit. It also embraced the new financial ontology of interdependence as the foundation of a new financial architecture that would be used for reinvigorating growth. Realizing that the money market could be reined in only at great economic and hence political costs, nominalists simply allowed banks to leverage themselves relying on the credit circuit generated by the money markets.

Nominalists brought the intelligibility of systemic risk into focus during an ongoing discount window study. This project was organized by Fed governor George Mitchell, who was appointed by President Kennedy in 1961 to break the substantivists' reign (Bremner, 2004, pp. 160-61). As the first initiative to implement the nominalist project, it was launched to redesign the discount window into a tool to encourage rural banks to lend more freely to their communities, thereby enabling the banking system to reach its "optimum performance" in maximizing growth. Blaming credit undersupply to rural areas on the 1955 discount window reform (FRB, 1968, pp. 52-56), nominalists saw the window as a tool to unleash risk-taking in the system's underleveraged parts (Ibid., pp. 1-7). The threat of the 1966 crunch, however, radically reoriented the study's focus toward the question of how to govern such an implosive 
ontology.

In response, nominalists problematized crunches as a new form of financial emergency, "limited liquidity crisis." This discursive frame performed boundary-work (Gieryn, 1983) between the Fed and the money market, preventing the overflow of crunches onto the Fed as a governance crisis. This new classificatory category denoted a systemic disruption in the credit circuit generated by the money market. These crises were triggered by the failure of a financial institution in the money market due to a "random asymmetrical event," such as management failures and unforeseen changes in economic conditions. Moreover, they were inherent to the growing "interdependence and interaction among institutions" in money markets (FRB, 1968, pp. 16-17).

This frame allowed nominalists to speak about the externalities created by money market devices' overflow, particularly federal funds and CDs, without condemning them as destabilizing. To put it in Callonian (1998a) terms, this problematization assumed that the overflow was not due to the inherent way in which these instruments constituted market relationships, but to the risk management practices' imperfections. As Muniesa (2015, pp. 49, 59-60) points out, finance depends on financial assets' continuous disentanglement from lenders and their re-entanglement to borrowers. In crunches, this process breaks down. Either lenders stop disentangling assets out of fear and distrust of their counterparties (gridlocks), or lenders get caught up in a situation where the borrowers cannot disentangle themselves from loans (cascading failures). While the Fed's provocation of these markets in 1966 actualized systemic risk as an intelligible and thus explicit property of the new financial ontology, nominalists construed crunches as a transient problem that would subside with the rationalization of risk management.

Furthermore, nominalists embraced money markets as a technical solution to the nation's socio-political problems; by enhancing money markets' capacity to generate credit, finance could perform as a growth engine to reinvigorate prosperity. Such a task required the Fed to repurpose its policy tools-OMOs, the discount window, and reserve requirements - so that finance could function as a policy infrastructure. In this new role, the financial system acted as a "monetary policy transmission mechanism" that translated OMOs into macroeconomic effects.

The production of these effects, however, depended on a complex intermediation process 
that took place in money markets (Cook and LaRoche, 1993). OMOs intervene in the ff market to influence the ff rate. In this market, banks borrow each others' excess reserves overnight to fulfill reserve requirements. By trading Treasuries the Fed determines the cost of borrowing reserves (i.e. the ff rate). Rates in other money market segments, in turn, are determined vis-a-vis the ff rate. Because the prime rate, which determines borrowing costs of consumers and nonfinancial companies, depends on the money market rates, the Fed can influence economic activity by manipulating the ff rate. The Fed's ability to manage growth, therefore, depends on money markets' capacity to generate ample liquidity so that banks can leverage and increase long-term credit supply.

Money markets' susceptibility to crunches, however, meant that implementing the nominalist project depended on the Fed's willingness to "play an effective role as 'lender of last resort." The Fed could no longer resort to credit control tools, particularly reserve requirements, since they could provoke an overflow in money markets. And the discount window had to be redesigned to serve as the backbone of a financial emergency mitigation strategy against crunches. In "general or isolated emergency situations," the window would supply liquidity to banks, and under extreme conditions, it would "provide circumscribed credit assistance to a broader spectrum of financial institutions." The Fed had finally come to see itself as "the ultimate source of liquidity to the economy" and thus responsible for the entire financial system's security (FRB, 1968, p. 2).

\section{Mitigating Systemic Risk}

Nominalists institutionalized the emergency mitigation strategy as FELP in 1970, only a few months into Burns' tenure. Since the 1940s, Burns had been a leading proponent of monetary government. As Eisenhower's chief economic adviser in the mid-1950s, he had facilitated the establishment of the Commission on Money and Credit in 1957 to study whether finance could become a growth engine (Schriftgiesser, 1973). The CMC, bringing together policy elites from the Roosevelt, Truman, and Eisenhower administrations, outlined a roadmap for macroeconomic governance: make the Fed the central locus of macroeconomic governance, conduct monetary policy through OMOs, and free finance from its substantivist shackles (CMC, 1961). Although 
the CMC had also emphasized the importance of the Fed's lender of last resort function, it had prescribed this function's use against Milton Friedman's concept of "general liquidity crises," which denoted a collapse in the volume of money in the economy (most often through a run on banks by depositors), as opposed to liquidity crunches in the money market.

FELP, however, did not simply protect money markets. It also, to put it in the words of Mary Douglas (2002), shielded the purity of the monetary and financial architectures from the dangers of the new financial ontology. FELP purified the state-economy boundary separating the Fed from finance by reframing money market overflows as financial emergencies. This purification operated through two security mechanisms, containment and controlled liquidation (see Figure 3). The former was used in response to sudden, unpreventable catastrophic bankruptcies, where either the failing institution was not a member bank or it did not have good collateral. The Fed bolstered the affected banks' reserves, and banks, in turn, absorbed the shock by acting as a buffer. Controlled liquidation kicked in in situations where containment was impossible. The Fed lent directly to the failing bank as well as indirectly to a consortium of banks until one of three things happened: the failure could be mitigated by containment, the bank merged with another bank, or alternatively the FDIC recapitalized it.

Ironically, FELP, in its containment mode, was deployed for the first time in response to an industrial firm's failure, the Penn Central Railroad Company, in the summer of 1970. The Fed intervened because of the company's sizable presence in the commercial paper market on which nonfinancial corporations relied for liquidity. A liquidity crisis in this market could have spread to the rest of the money market through the feedback loop of CDs. Penn, however, did not qualify for a direct loan. So, the Fed lent instead to the money market banks to ensure that, if the market froze, banks could provide liquidity to nonfinancial companies. The discount window acted as a de facto government guarantee on bank loans, and this, in turn, prevented a liquidity crunch.

Controlled liquidation proved more controversial. In 1974, the Fed faced an unmatched public outcry for rescuing Franklin National Bank, the largest bailout to date. The task of purifying the Fed fell on Governor Andrew Brimmer who had led both rescues. Brimmer, the first governor with a Ph.D. in economics, was appointed by President Johnson in 1966 to marginalize the substantivists. He should be considered as the first mutation in nominalism 
Writing Sample

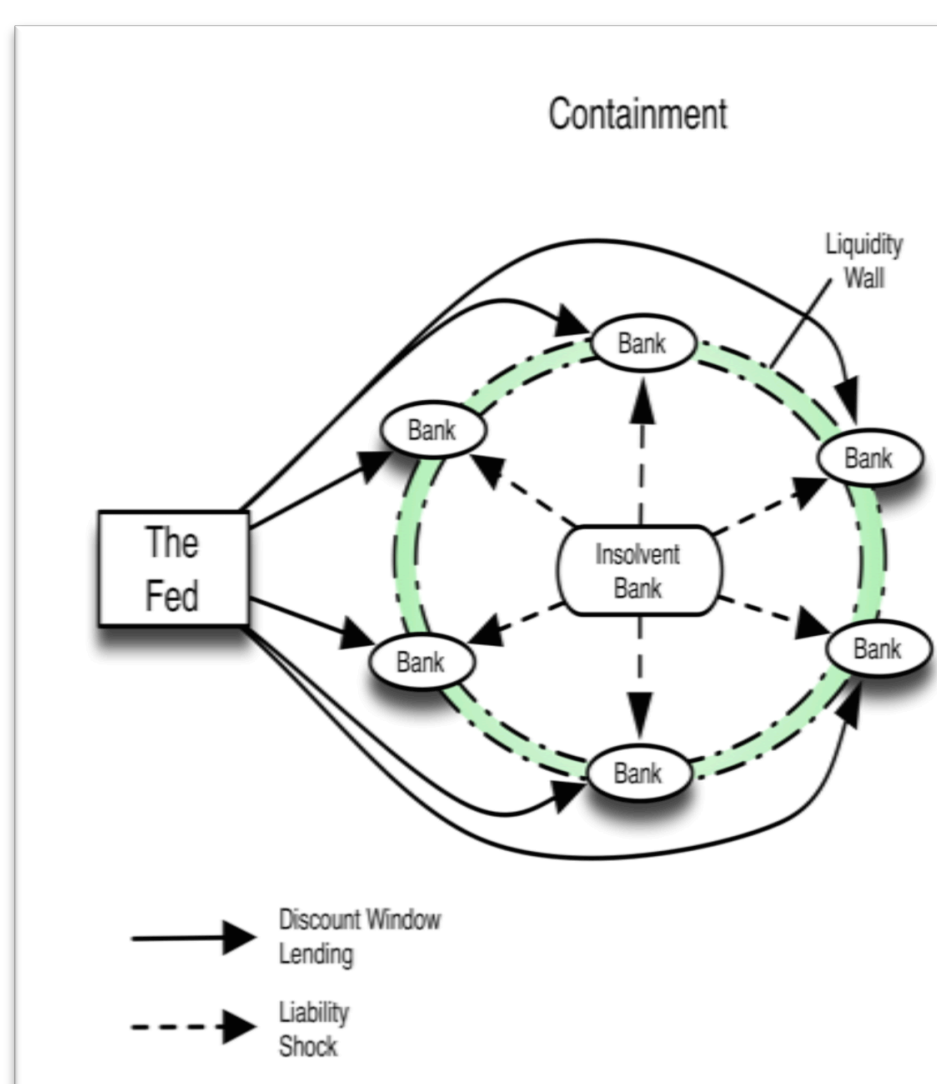

Onur Özgöde

Controlled Liquidation

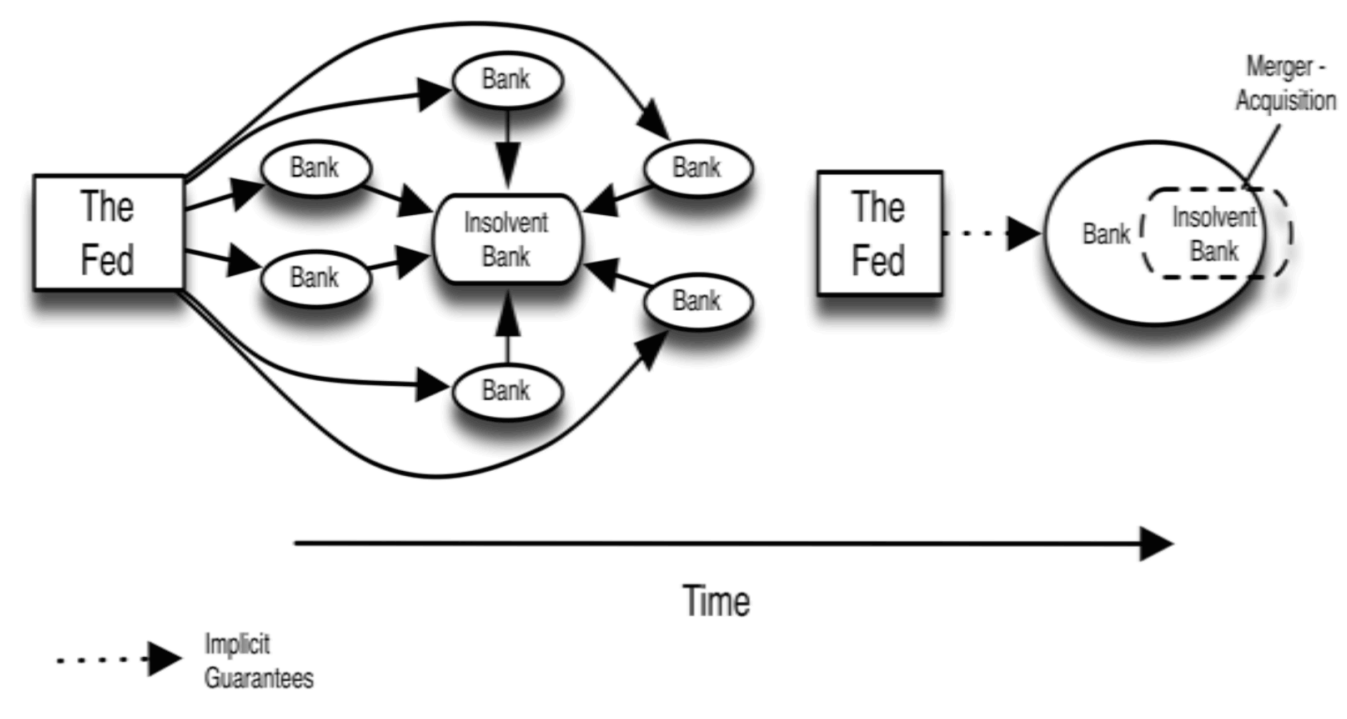

Figure 3: The Emergency Mitigation Mechanisms

This figure was constructed based on Governor Andrew Brimmer's accounts $(1976 ; 1989)$ on the Fed's interventions in bank 
toward a systemic mold. During graduate school at Harvard, he was part of Wassily Leontief's interindustry economics project to model the US economy as an interdependent input and output (I-O) system. However, he completed his dissertation under Alvin Hansen on monetary policy and finance (Brimmer, 2003). This unique combination of expertise allowed Brimmer to rearticulate the problem of liquidity crunches in a systemic mode and thereby reframe the discursive overflow precipitated by FELP as good governance.

Brimmer's reframing rested on the ethical proposition that the Fed has a responsibility for the security of finance as a vital economic system. To understand the Fed's decision to lend $\$ 1.7$ billion to an insolvent bank, he argued, one had to conceive of its lender of last resort function "beyond the simple conception of the Federal Reserve as a lender to member banks in distress." Instead, the Fed had the "fundamental responsibility for the health and functioning of the financial system as a whole" (Brimmer, 1976, pp. 109, 129). Franklin was heavily invested in ff, $\mathrm{CD}$, and Eurodollar markets. Because in these markets banks were part of a "[h]ighly developed network of banking relationships," Brimmer argued that the Fed's actions should not be misconstrued as a bailout. Instead, the Fed had acted to fulfill its responsibility to protect solvent financial institutions that would have been rendered insolvent due to their exposure to Franklin in the money market (Brimmer, 1989, p. 4).

The Franklin rescue was critical for the construction of systemic risk. The Fed admitted how critical money markets were. Protecting them would enhance the efficient allocation of the funds banks held in deposit accounts to productive sectors, because the security of a permanent liquidity put through FELP would increase banks' willingness to loan out excess reserves. Thereby, it would make credit cheaper and promote growth. This strategy, however, brought with it a new source of vulnerability as banks became more leveraged and more dependent on short-term liquidity, further increasing the system's susceptibility to crunches. Moreover, FELP performed the very interdependencies it protected. Bolstered by the Fed's liquidity put, banks spent the 1970s collecting funds from regional and rural banks, as well as recycling the petrodollars through the Eurodollar market, to make syndicated loans to developing countries. These simultaneous processes not only expanded interconnectedness and the reach of crunches to new parts of a globalizing financial system. They also increased bank leverage and thereby made the system more vulnerable to a new threat—-sovereign defaults_ - as the Latin American debt crisis 
would reveal the next decade (Kapur et al., 1997, p. 608).

\section{Expanding FELP's Jurisdiction}

By 2010, FELP's jurisdiction had expanded to situations related to non-bank financial institutions, including private investors, securities brokerage firms, hedge funds, insurance companies, and investment banks. This expansion was driven by the new financial architecture. Under the assumption that the catastrophe risk in the system was the aggregate of financial institutions' risks, this architecture relied on a distributed risk management regime in which firms managed their own risks. Risk management techniques would format uncertainties into risks, allowing leverage without raising default risk.

By spreading risks, however, devices, particularly derivatives, formed new interdependencies. New interdependencies' interaction with already existing ones in the money market resulted in a new overflow that exceeded risk management's limits. In this new state, financial firms operated in an ecology of ignorance (Luhmann, 1998) in which firms could not know what they did not know, particularly their counterparty risks. Making matters worse, the Fed found itself managing a system whose behavior under extreme distress was inherently indeterminate. As Brian Wynne (1992, pp. 114-16) notes, the indeterminate nature of complex systems means that their regulation cannot simply rely on risk management at the firm level. Since such systems cannot be governed through private insurance mechanisms either (Beck, 2008), the Fed had to become an insurer of last resort (Moss, 2004) to an increasing array of institutions.

The new financial architecture was tested during the 1975 New York City bankruptcy. Barred from debt markets, local officials appealed to an unsympathetic Ford administration for a bailout. Inverting the Fed's justification for FELP, they insisted that a bankruptcy would "trigger a long line of falling dominoes" in the banking system (Orlebeke, 1993, p. 363). Dismissing these warnings as fearmongering, Burns persuaded Ford not to give the bailout. By October, however, the crisis became international; German and French leaders warned Ford about the default's impact on the global financial system. Helmut Schmidt, pointing to the Franklin failure cautioned that the default would have a "domino effect, striking other world financial centers" 
(quoted in Lachman and Polner, 2010, pp. 152-53).

By late October, Burns was also convinced that a bankruptcy could trigger a panic. At a congressional hearing, he nevertheless insisted that the default could be contained (Debt Financing Problems, 1975, pp. 1649-51; Orlebeke, 1993, p. 363). In contrast, John Heimann, the New York State superintendent of banks, underscored the indeterminacy surrounding the event. Only Merlin with "an unclouded crystal ball," he noted, could determine the impact in such an interdependent society. "Whether the risk in permitting this default [...] was worth taking" depended on what was at stake: "is it the whole system by which we finance state and local governments? Or is it the capital structure of the free world?" Since it was impossible to predict the outcome, the worst had to be assumed (Debt Financing Problems, 1975, pp. 1118-120).

In mid-November, a Fed study revealed the banking system's vulnerability to a default. Distressed city and state debt amounted to 30 percent of the capital of the eleven largest banks, and there was already a reduced willingness to lend to them. Signs of a looming liquidity crunch had already become visible in federal funds and CDs; while banks were trying to move away from overnight ff loans toward longer maturity CDs, investors were shying away from CDs. Consequently, liquidity costs were raising (FRB, 1975, p. III-3-9; Dale, 1975). At this point, after the Fed determined the threat to be credible, the city was bailed out to protect the money market.

"Systemic risk" was first uttered as a boundary object to differentiate public matters of financial stability from private matters of risk management during a congressional hearing on the unpalatable rescue of billionaire commodity speculators, Hunt brothers, in 1980. During the 1970s, Hunt brothers had acquired more than two-thirds of the world's silver supply and futures contracts. When the Chicago Mercantile Exchanged imposed restrictions on silver trading, securities brokerage firms that extended credit to the Hunts experienced difficulties. As plunging prices put these firms on the brink of bankruptcy, the Fed feared that banks were also at risk and persuaded a consortium of banks to rescue the Hunts (Brimmer 1989).

At the congressional hearings on the bailout, Fed chairman Paul Volcker and Heimann, now the Comptroller of the Currency, defended their actions by invoking the term "systemic risk." According to Volcker, the bankruptcy would have "trigger[ed] massive liquidation of 
silver positions to the peril of all creditors, [...] indirectly placing in jeopardy the customers and creditors of those institutions in a financial chain reaction." He argued that "the potential vulnerability of banks and other intermediaries" necessitated an intervention to prevent "severe financial disturbances." Heimann contended that the bankruptcy would have posed "systemic risks" to the banking system (Silver Prices, 1980, pp. 208-13).

This discursive strategy allowed policymakers to translate the indeterminacy surrounding liquidity crunches into the discursive certainty of a systemic collapse. Unlike other metaphors with origins in international relations and chemistry, such as "domino effects" and "chain reaction," "systemic risk," borrowed from medicine, referred to death caused by the collapse of one of the body's main systems due to a singular event such as heart attack. Thus, it signified the certainty that if realized, the outcome would be so devastating that even if the probability of collapse were next to zero, the failure should have been mitigated in the first place. By emphasizing catastrophic outcome, this discursive strategy allowed the Fed to purify FELP's expansion into new parts of the financial sector. And more importantly, "systemic risk" signaled that the problem FELP addressed was about the "systemic" properties of a system, and not the "risks" accrued. In other words, "systemic risk" is not a risk concept per se; it rather marks the limit of the Fed as an insurer of last resort and underscores the necessity of reducing vulnerabilities in advance.

The question that remains is why both actors cautioned against regulating futures markets when it was becoming evident that liquidity crunches were an inherent feature of the new financial architecture. The answer lies in their diagnosis of the crisis and the function they attributed to future contracts. Heimann argued the episode was caused by "extreme speculative manipulation." Therefore, crunches resulted from a deviation from the norm of responsible financial conduct. Furthermore, the frequency of such events could be minimized by enhancing market discipline. Therefore restrictions were undesirable, since they "significantly impede the ability of the market to function efficiently." After all, these markets, he argued, fulfilled “entirely appropriate roles of providing liquidity and translating or limiting risk" (Ibid., pp. 21113). Both actors in short insisted that financial innovation lowered aggregate risk in the system and that occasional overflows could be safely contained. 


\section{Reframing Systemic Risk}

The overflow of politics and finance onto the Fed not only forced nominalists to enhance the banking system's resilience but also fractured them into factions advocating competing strategies to accomplish this task. An emergent systemic faction invented the concept of "systemic risk" as a systemic vulnerability inherent to the system and developed vulnerability reduction as a new strategy to reframe the overflow of finance. In contrast, the dominant faction, consisting of policy elites, mobilized this new discursive object to offset the overflow of politics, but they took an aggregative position on enhancing the system's resilience and reintensified the distributed risk management apparatus.

The systemic position was formed during a project on large-value payment and settlement systems. Nominalists were concerned that the Clearing House Interbank Payment System (CHIPS), a private system with which banks settled their EuroDollar market loans, was becoming a threat to money markets. The Fed was a creditor to these banks through its domestic payment system - FedWire - and therefore, an overflow in CHIPS could destroy its autonomy. Because it was politically inconceivable for the Fed to bail itself out (Edward Ettin, interview, March 8, 2018), CHIPS marked the limit of emergency mitigation; the only possible strategy was vulnerability reduction. This strategy, however, was implemented as an ad hoc supplement to emergency mitigation.

Nominalists detected payment system risk around 1979 when the FedWire operations chief warned Volcker that a small bank was holding intraday overdraft positions that exceeded its capital. Volcker asked his special assistant, Gerald Corrigan, as well as the Research Division's deputy director, Edward Ettin, to address the issue. Ettin recruited David Humphrey, chief of the Research Division's Financial Studies Section. Like Brimmer, Humphrey was trained in I-O analysis during his doctorate, and before joining the Fed in 1975 he worked in the Interindustry Economics Division of the Bureau of Economic Analysis in the Commerce Department. Humphrey's expertise in I-O modeling, exposed him to the work of systems analysts in other parts of the state who were retooling this technique into a vulnerability measurement tool for enhancing the resilience of economic systems, such as energy networks (Humphrey, interview, February 17 and 20, 2018). Humphrey’s affinity with systemic 
techniques signaled the formation of a niche for systems analysis expertise that would become the backbone of vulnerability reduction in the coming decades.

In the wake of the 1984 Continental Illinois Bank rescue, the largest bank failure to date, another member of the group, Cleveland Fed vice president, Edward Stevens, recognized a worrisome trend in payment systems. Since 1970, the daily settled value with banks' reserves at the Fed had increased from $\$ 30$ billion to $\$ 520$ billion. In contrast, banks' reserve deposits at the Fed stalled at \$20 billion. In effect, banks’ leverage against the Fed had skyrocketed from 1.5 times to 26 (Stevens, 1984, pp. 11-13). Given the rise in the popularity of CHIPS and the astronomical increase in the value of transactions settled through LVPS systems (see Figures 4), this was disconcerting.

Stevens assumed that only CHIPS, and not FedWire, was susceptible to systemic risk (cascading failures) — though 9/11 attacks would reveal FedWire's susceptibility to gridlocks. Whereas FedWire operated on a real-time gross settlement (RTGS) regime, CHIPS depended on a deferred net settlement (DNS) regime. Banks preferred the DNS regime because it was less costly and more efficient; however, it was more vulnerable to settlement failures. In DNS-based systems, there was a temporal gap between a settlement and payment, and payments were provisional. Furthermore, because DNS regimes worked on a netting basis, settlements were temporally interdependent on each other, making it more likely that a settlement failure would trigger cascading collapses.

A breakthrough in the explication of systemic risk was reached due to a 1981 settlement rule change in CHIPS - shift from next-day to same-day settlements. This reform was supposed to reduce settlement risk, but in effect increased systemic risk. Recognizing that an attempt to make individual banks safer (risk reduction) could make the system less secure (increase in vulnerability), Stevens concluded that systemic risk was neither simply the realization of idiosyncratic risks. Nor was it a transient problem that would dissipate with the rationalization of risk management. One could not simply reduce specific risks and expect systemic risk to decrease. Instead, systemic risk was a structural property of a system that depended on institutional rules and arrangements (Stevens, 1984, p. 15). The implication was a major blow to aggregative understanding of systemic risk, as it meant that risk management techniques could 


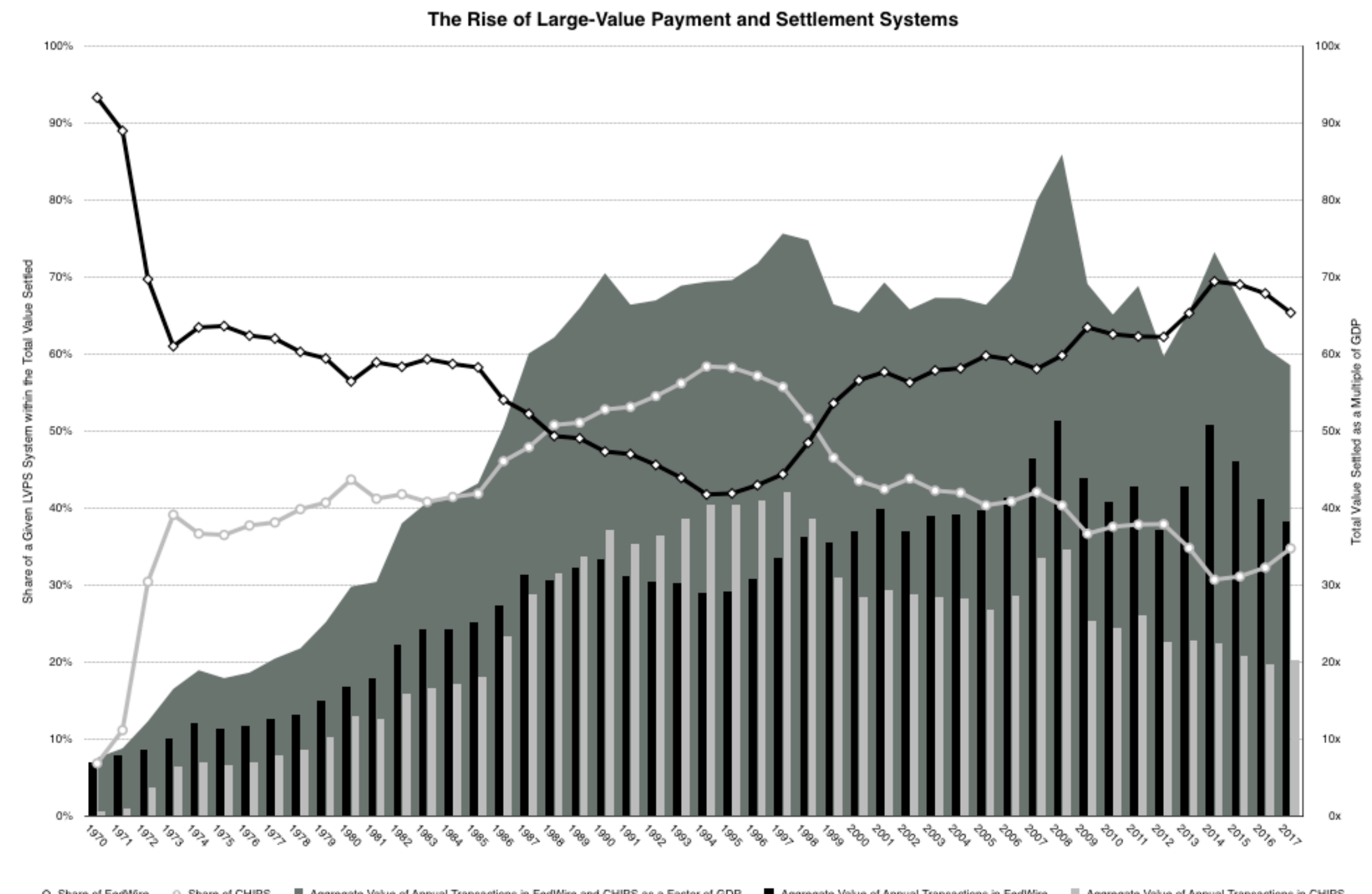


actually create new interdependencies and thereby foster systemic risk.

The Fed found itself in a catch-22. A settlement failure in CHIPS could easily result in the "vulnerability of many banks directly or indirectly to a single counterparty's failure to settle" and inflict significant damage on the system. Since the Fed had a responsibility to "protect the resilience of the banking system to an unexpected settlement failure," it had to manage "systemic risk" (Stevens, 1984, pp. 2, 8, 15-16). Thus, protecting its autonomy required the Fed to reduce CHIPS' vulnerability. This, however, required proving the existence of systemic risk. Lawmakers, already irritated by the Continental bailout, were skeptical of the Fed's justification of FELP in terms of systemic risk. And yet, banks were also reluctant to shift to a costlier settlement regime. On the one hand, letting a large bank fail to prove systemic risk was unimaginable. It could have catastrophic consequences, including a depression. On the other hand, mitigating CHIPS's failure would anger Congress even more. Thus, the only way to make systemic risk explicit while avoiding this catch-22 was to enact a "virtual experiment" through a simulation (Morgan, 2004).

Simulations allowed policymakers to enact virtual scenarios (Collier, 2008) through which one could assess the consequences of (in)action. Humphrey ran three iterative simulations of a settlement failure by a large bank in CHIPS. In the first two, all payments to and from the bank were removed, and other institutions' settlement positions in CHIPS were calculated for pre- and post-failure states. The third simulation demonstrated the effects of the failure of a second large participant triggered by the primary failure. The conclusion was that the failure could have bankrupted nearly half of the participants and one-third of the transaction value.

According to Humphrey (1986, pp. 102-08), the "degree of systemic risk" posed by a default depended on two factors. The vulnerability increased with the shock's suddenness and unexpectedness, since institutions would have less time to reduce their exposures to default. The shock's impact depended on the number of affected institutions, the magnitude of their exposure, and the size of the failing institution.

Humphrey's simulations revealed the extent to which the financial system had become a hybrid entity that was simultaneously part of both the state and the economy. Because banks on CHIPS were the same banks that benefited from intraday credits in FedWire, the Fed was also 
exposed to their credit risks in CHIPS. The fact that the Fed was tacitly the insurer of FedWire made it also the insurer of risks in CHIPS. Thus, ironically, repairing this breach in the privatepublic boundary meant that if the Fed were to reduce systemic risk in CHIPS - that is, purify CHIPS's status as part of both the state and the economy - it had to become further entangled in the operations of a private enterprise. Reducing vulnerability, after all, required state actors to not only redesign the institutional and operational rules governing a private market infrastructure, but also to monitor future changes in these rules on an ongoing basis.

The Fed was thus in a double bind, trapped in a structural position that required it to subsidize liquidity for banks for the sake of ensuring the system's resilience. While it could singlehandedly reduce or even eliminate FedWire's vulnerability and protect itself from credit risk, such a move would increase systemic risk in CHIPS (FRB, 1988, pp. 4-5). As a solution, Corrigan's group proposed charging a penalty for overdrafts in FedWire. This would lower systemic risk in CHIPS by correcting the mispricing of credit risk a la intraday credits in FedWire. The aim of this first attempt to reduce the system's vulnerability was to free the Fed from the precarious structural position it held vis-à-vis CHIPS. Penalty pricing was eventually instituted in 1994, and per the Fed's recommendations, CHIPS moved to a less-vulnerable realtime intraday netting regime in 2001 (Martin, 2005, pp. 42-51)

At the scale of the banking system, however, nominalists took an aggregative position on systemic risk and implemented the Basel Accords in 1988 to reinforce the state-economy boundary. The aggregationist approach focused on the safety of individual banks and reformatted bank capital as a shock-absorption device. The Accords, based on the assumption that financial risk is a multifaceted phenomenon that could be categorized into risk categories, conceived systemic risk as a byproduct of these idiosyncratic firm-level risks. Accordingly, it deployed risk regulation instruments such as risk-adjusted capital adequacy ratios (CARs), value at risk (VaR), and stress tests to reduce the aggregate catastrophe risk in the system by enhancing the resilience of banks.

Under the initiative of Corrigan, now New York Fed president, nominalists instituted CARs to stem the secular rise in bank leverage since the 1960s while not suppressing the money 
market. The average bank capital ratios had declined from 8 percent to 6 percent in 1981 (Burhouse et al., 2003). At a hearing on capital requirements in 1987, Volcker admitted this decrease was disconcerting because of "capital's role as a buffer to absorb unexpected losses." Eroding capital levels were a serious threat, since this decline was correlated with "the likelihood of bank failures." To "fulfill [its] strategic role" of promoting growth, the banking system had to remain strong (Risk-Based Capital Requirements, 1987, pp. 3-7). In 1981, the Fed introduced numerical minimum capital requirements (a simple ratio of primary capital to total assets) to serve as a floor on the degree to which the system could take on more leverage without becoming vulnerable. While successful, this intervention led to unexpected distortions by encouraging banks to shift their portfolios to illiquid, higher-risk assets, magnifying the system's vulnerability as standards failed to take into account the differences in liquidity and riskiness between asset classes (Burhouse et al., 2003). CARs were supposed to address this adaptive overflow.

CARs also had a secondary function - to replace Glass-Steagall. Corrigan argued the system was undergoing a revolutionary transformation due to financial and technological innovation, and the question was how to govern it. Ruling out reregulation and deregulation, Corrigan advocated a third alternative: letting Glass-Steagall's firewalls erode while continuing to treat finance as a special sector (Corrigan, 1987, pp. 6, 10). This entailed the reconstitution of the distributed risk management apparatus as a surveillance mechanism centered around CARs. The increasing temporal and spatial complexity of markets, admitted Corrigan, had led to the emergence of a system that accrued mega credit exposures. And these exposures were becoming increasingly interconnected through an "intricate web of interdependencies" that made the system unpredictable. Thus, in addition to boosting confidence in the system at a time of assumed fragility due to increased "degree of operational, liquidity and credit interdependency," CARs were supposed to strengthen the system without undermining its complexity (Ibid., pp. 3, $21-30,42)$.

Under Corrigan's chairmanship, the Basel Committee complemented CARs with VaR and stress testing in the 1990s. VaR monitored the probability of a firm incurring a sizable loss under normal market conditions (Holton, 2002). Stress testing, in contrast, assessed the 
vulnerability of banks to low probability but catastrophic disruptions by "evaluat[ing] the capacity of capital to absorb" shocks (BCBS, 1996, pp. 46-47). While VaR translated the uncertainty of bankruptcy into default risk through the frame of normal distribution, stress tests performed this function with power law distribution frames for extreme situations that were so rare they could not be captured by normal distribution.

The Basel reforms, however, were plagued with politico-economic weaknesses. CARs reconceptualized capital as a stockpile of assets with varying degrees of shock-absorbing properties. The capacity of these assets to absorb shocks depended on their ability to insulate capital from external distresses. In this sense, resiliency depended on preventing the overflow of the boundary separating bank capital from firm's environment. This, however, was costly. The relevant question, therefore, was not whether an overflow could be prevented, but whether banks would bear such costs. A case in point was Goldman Sachs's response. Clinton's Treasury Secretary Robert Rubin (2003, p. 343), the company's former co-chairman, recalls that after considering to prepare for a "systemic financial collapse," the firm "concluded that if we really wanted to take into account every catastrophic contingency, we couldn't be in business." Thus, as long as the Basel framework left worst-case scenarios' design to banks, stress tests could not serve its intended function of reframing the overflows in $\mathrm{VaR}$.

More importantly, the Basel reforms' formatting of systemic risk were deeply flawed. Aggregative nominalists misrecognized aggregate financial risk as tantamount to systemic risk. For actors like Corrigan (1992), who urged regulators to "operate on the assumption that systemic risk may be greater" in the future, their central concern should have been the overflow of CARs through the astronomical growth of off-balance sheet activities relying on derivatives, and not the interlinkages produced by them. The problem, thus, was not construed as the interdependencies, but as the accumulation of off-balance sheet risk pockets invisible to market actors. Alan Greenspan (2005) went further and defended derivatives as the source of the system's resilience. Consequently, the distributed risk management apparatus has remained blind to systemic risk-inducing interdependencies.

If systemic risk were to be rendered manageable, however, the vulnerability of systemic interdependencies had to be reduced at the scale of systemically important, critical nodes. Unsurprisingly, the technical capacity to monitor and reduce these vulnerabilities was developed 
in the 2000s by systems analysts at the NY Fed who came to occupy the expertise niche that Humphrey had established. Despite NY Fed president Tim Geithner's (2006) warnings that money market simulations had showed that the new system was prone to sudden phase transitions from resiliency to fragility, a vulnerability reduction regime was created under the 2010 Dodd-Frank Act only after the crisis when systemic faction leveraged the crisis to convince the Obama administration that both FELP and the distributed risk management apparatus had reached their limits in reframing the overflow of finance and politics.

As Geithner warned the Federal Open Market Committee (FOMC) two days after the Bear Stearns rescue, the Fed was once again facing the risk of "becom[ing] the counterparty to everybody," just as it did in CHIPS. To avoid such an overflow, the Fed had to "make sure that [FELP was ...] not a backstop that's so attractive that they [all] come;" yet, as he predicted, "that [was] going to be a very hard line to walk." Indeed, this is why the Fed let Lehman Brothers fail six months later. In the FOMC meeting on September 16, Boston and Kansas Fed presidents underscored the necessity of taking "a calculated bet" in letting Lehman go, "because we did have a market beginning to play $[\mathrm{sic}]$ the Treasury and us" (Popper and Schwartz, 2014). As LaWare had predicted nearly two decades ago, the price the Fed and the rest of the world paid for maintaining the purity of FELP turned out to be neither politically nor economically acceptable. This is precisely why Geithner, then the Treasury Secretary, and the Fed, facing the most serious existential threat to date, finally remapped the vulnerability reduction strategy onto the rest of the financial system as an autonomous, complementary security apparatus in 2010.

\section{Conclusion}

This paper examined the construction of systemic risk as a pathology of monetary government. It argued that systemic risk is both the effect of the pathological overflow of the financial architecture through which the Fed governs the economy and a discursive object at the heart of the practices designed to purify this overflow and the breaches these practices cause in the state-economy boundary. This is precisely why systemic risk is neither a recent "social construct" that masks more fundamental problems nor an ahistorical sui generis property of financial systems. It is rather a historically specific symptom of an imbalance in economic governance caused by the substitution of monetary governance for fiscal policy and the 
consequent reliance on short-term credit as the engine of growth and prosperity. This is why the more the Fed overtook macroeconomic governance, the more it became captured by systemic risk and thereby put itself in an ever more politico-economically precarious position. While the materialization of the vulnerability reduction strategy into a systemic risk regulation regime is a step forward, as long as we insist on monetary governance alone to solve our socio-economic problems through growth, systemic risk will persist and the Fed will remain under its spell.

Short of fiscal redistribution, vulnerability reduction will determine the fate of monetary government as the last hope of the political liberal project to govern the economy at a distance. As each systemic crisis calls into question the credibility of both finance and the Fed as quasipublic goods (Carruthers, 1996), the inability to reduce and control systemic risk, thus, may have effects beyond the economy: the collapse of the Fed as the last governmental space of macroeconomic expertise insulated from politics. As Krippner (2011) rightly points out, one strategy that made this possible was the Fed's reliance on (money) markets for allocating resources. At the heart of this decision was Regulation Q's rollback; as this paper showed, this decision was a direct response to the emergence of systemic risk. This is why unless systemic risk is reduced, the Fed will find itself confronted with unavoidable political questions to which it may not have answers. Given the incompatibility of systemic risk with credit control tools, what is at stake, therefore, is the fate of not just the economy but also the Fed, and thus monetary government, as a utopia of macroeconomic governance.

\section{References}

Basle Committee on Banking Supervision [BCBS] (1996) Amendment to the Capital Accord to Incorporate Market Risks, Basle, BCBS.

Beck, U. (2008) World at Risk, Cambridge, Polity.

Block, F. (1994) 'The Roles of the State in the Economy'. In Smelser, N. and Swedberg, R. (eds) The Handbook of Economic Sociology, Princeton, Princeton University Press, pp. 691710.

Board of Governors of the Federal Reserve System [FRB] (1968) Reappraisal of the Federal Reserve Discount Mechanism, Washington, DC, FRB. 
Board of Governors of the Federal Reserve System (1975) Current Economic and Financial Conditions, Washington, DC, FRB.

Board of Governors of the Federal Reserve System (1988) Controlling Risk in the Payments System, Washington, DC, FRB.

Bockman, J. and Eyal, G. (2002) 'Eastern Europe as a Laboratory for Economic Knowledge: The Transnational Roots of Neoliberalism', American Journal of Sociology, 108, 310-352.

Bremner, R. (2004) Chairman of the Fed: William McChesney Martin Jr., and the Creation of the Modern American Financial System, New Haven, Yale University Press.

Brimmer, A. (1976) 'The Federal Reserve and the Failure of Franklin National Bank: A Case Study of Regulation'. In Backman, J. (ed) Business and the American Economy, 17762001, New York, New York University Press.

Brimmer, A. (1989) 'Central Banking and Systemic Risks in Capital Markets', Journal of Economic Perspectives, 3, 3-16.

Brimmer, A. (2003) Interview by Larry Crowe, April 24, interview A2003.090, Session 1, tape 8, story 4, HistoryMakers Digital Archive.

Burhouse, S., Feid, J., French, G. and Ligon, K. (2003) 'Basel and the Evolution of Capital Regulation', FDIC, accessed at http://www.fdic.gov/bank/analytical/fyi/2003/011403fyi.html on February 28, 2014.

Callon, M. (1998a) 'An Essay on Framing and Overflowing: Economic Externalities Revisited by Sociology'. In Callon, M. (ed) The Laws of the Market, pp. 244-269.

Callon, M. (1998b) 'Introduction'. In Callon, M. (ed) The Laws of the Markets, Oxford, Blackwell Publishers, pp. 1-57.

Carruthers, Bruce (1999) City of Capital: Politics and Markets in the English Financial Revolution, Princeton, Princeton University Press.

Centeno, M., Nag, M., Patterson, T., Shaver, A. and Windawi, J. (2015) 'The Emergence of Global Systemic Risk', Annual Review of Sociology, 41, 65-85.

Collier, S. J. (2008) 'Enacting Catastrophe: Preparedness, Insurance, Budgetary Rationalization', Economy and Society, 37, 224-250.

Commission on Money and Credit (1961) Money and Credit: Their Influence on Jobs, Prices, and Growth, Engelwood Cliffs, NJ, Prentice-hall.

Cook, T. and LaRoche, R. (eds) (1993) Instruments of the Money Market, Richmond, Federal Reserve Bank of Richmond. 
Corrigan, E. G. (1992) 'Challenges Facing the International Community of Bank Supervisors', Quarterly Review-FRBNY, 17, 1-9.

Corrigan, G. (1987) Financial Market Structure: A Longer View, New York, FRBNY.

Çalışkan, K. and Callon, M. (2009) 'Economization, Part 1: Shifting Attention from the Economy towards Processes of Economization', Economy and Society, 38, 369-398.

Dale, E. (1975) 'Large Banks Hold Big Stakes Here', New York Times (14 November 1975).

Davis, G. (2009) Managed by the Markets: How Finance Reshaped America, New York, Oxford University Press.

Debt Financing Problems of State and Local Government: The New York City Case : Hearings Before the Subcommittee on Economic Stabilization of the Committee on Banking, Currency and Housing, House of Representatives, 94th Congr., $1^{\text {st }}$ Session, (1975).

Douglas, M. (2002) Purity and Danger: An Analysis of Concepts of Pollution and Taboo, New York, Routledge.

Economic Implications of the 'Too Big to Fail' Policy: Hearing before the Subcommittee on Economic Stabilization of the Committee on Banking, Finance, and Urban Affairs, House of Representatives, 102nd Congr., $1^{\text {st }}$ Session First Session, (1991).

Eyal, G. (2000) 'Anti-Politics and the Spirit of Capitalism: Dissidents, Monetarists, and the Czech Transition to Capitalism', Theory and Society, 29, 49-92.

Eyal, G. (2003) The Origins of Postcommunist Elites: From Prague Spring to the Breakup of Czechoslovakia, Minneapolis, University of Minnesota Press.

Foucault, M. (1972) The Archeology of Knowledge, London, Tavistock.

Foucault, M. (1977) Discipline and Punish, New York, Vintage Books.

Foucault, M. (2007) Security, Territory, Population, New York, Picador.

Fourcade, M. (2007) 'Theories of Markets and Theories of Society', American Behavioral Scientist, 50, 1015-1034.

Fourcade-Gourinchas, M. and Babb, S. (2002) 'The Rebirth of the Liberal Creed: Paths to Neoliberalism in Four Countries', American Journal of Sociology, 108, 533-579.

Friedman, M. (1974) Interview with Milton Friedman: Franklin National. Sound Recording 146. Ed. Rose D. Friedman. Instructional Dynamics, Online Archive of California. 
Geithner, T. (2006) 'Risk Management Challenges in the U.S. Financial System', speech delivered to the Global Association of Risk Professionals (GARP) 7th Annual Risk Management Convention \& Exhibition, New York, February 28.

Gieryn, T. (1983) 'Boundary-Work and the Demarcation of Science from Non-Science: Strains and Interests in Professional Ideologies of Scientists', American Sociological Review, 48, 781-795.

Greenspan, A. (2005) 'Economic Flexibility', speech delivered at the National Association for Business Economics Annual Meeting, Chicago, September 27.

Hall, P. (1993) 'Policy Paradigms, Social Learning, and the State: The Case of Economic Policymaking in Britain', Comparative Politics, 25, 275-296.

Haydu, J. (1998) 'Making Use of the Past: Time Periods as Cases to Compare and as Sequences of Problem Solving', American Journal of Sociology, 104, 339-371.

Holton, G. A. (2002) History of Value-at-Risk: 1922-1998, Method and Hist of Econ Thought 0207001, EconWPA.

Humphrey, D. (1986) 'Payments Finality and the Risk of Settlement Failure'. In Saunders, A. (ed) Technology and the Regulation of Financial Markets, Lexington, MA, Lexington Books.

Johnson, S. and Kwak, J. (2010) 13 Bankers: The Wall Street Takeover and the Next Financial Meltdown, New York, Vintage.

Kapur, D., Lewis, J. and Webb, R. (1997) The World Bank: Its First Half Century, Washington, DC, Brookings Institution Press.

Krippner, G. R. (2005) 'The Financialization of the American Economy', Socio-Economic Review, 3, 173-208.

Krippner, G. (2007) ‘The Rise of Neoliberalism’, Contexts, 6, 67-69.

Krippner, G. (2011) Capitalizing on Crisis, Cambridge, Harvard University Press.

Kwak, J. (2013) 'Cultural Capture and the Financial Crisis'. In Carpenter, D. and Moss, D. (eds) Preventing Regulatory Capture, New York, Cambridge University Press, pp. 71-98.

Lachman, S. and Polner, R. (2010) The Man Who Saved New York Hugh Carey and the Great Fiscal Crisis of 1975, Albany, State University of New York Press.

Langley, P. (2016) Liquidity Lost, Oxford, Oxford University Press.

Latour, B. (1993) We Have Never Been Modern, Cambridge, Harvard University Press. 
Lounsbury, M. and Hirsch, P. (2010) Markets on Trial, Bingley, UK, Emerald.

Luhmann, N. (1998) Observations on Modernity, Stanford, Stanford University Press.

MacKenzie, D. and Millo, Y. (2003) 'Constructing a Market, Performing Theory: The Historical Sociology of a Financial Derivatives Exchange', American Journal of Sociology, 109, $107-145$.

Martin, A. (2005) 'Recent Evolution of Large-Value Payment Systems: Balancing Liquidity and Risk’, Economic Review, 90, 33-57.

Meltzer, A. (2010) A History of the Federal Reserve, Volume 2, Chicago, University of Chicago Press.

Miller, P. and Rose, N. (1990) 'Governing Economic Life’, Economy and Society, 19, 1-31.

Mitchell, T. (1991) 'The Limits of the State: Beyond Statist Approaches and Their Critics', The American Political Science Review, 85, 77-96.

Morgan, M. (2004) 'Simulation: The Birth of a Technology to Create «evidence» in Economics', Revue D’histoire Des Sciences, 57, 339-375.

Moss, D. (2004) When All Else Fails: Government as the Ultimate Risk Manager, Cambridge, Harvard University Press.

Muniesa, F. (2015) The Provoked Economy: Economic Reality and the Performative Turn, London, Routledge.

Muniesa, F., Millo, Y. and Callon, M. (2007) 'An Introduction to Market Devices'. In Callon, M., Millo, Y., and Muniesa, F. (eds) Market devices, Malden, MA, Blackwell Pub., pp. $1-12$.

Orlebeke, C. (1993) 'Saving New York: The Ford Administration and the New York City Fiscal Crisis'. In Firestone, B. and Ugrinsky, A. (eds) Gerald R. Ford and the Politics of PostWatergate America, Westport, CT, Greenwood Press.

Popper, B., Peter E., Annie L., Nathaniel and Schwartz, N. D. (2014) 'The Fed's Actions in 2008: What the Transcripts Reveal', The New York Times (21 February).

Prasad, M. (2006) The Politics of Free Markets: The Rise of Neoliberal Economic Policies in Britain, France, Germany, and the United States, Chicago, University of Chicago Press.

Risk-Based Capital Requirements for Banks and Bank Holding Companies: Hearing before the Subcommittee on General Oversight and Investigations of the Committee on Banking, Finance, and Urban Affairs, House of Representatives, 100th Congr., $1^{\text {st }}$ Session (1987). 
Rubin, R. E. and Weisberg, J. (2003) In an Uncertain World: Tough Choices from Wall Street to Washington, New York, Random House.

Schriftgiesser, K. (1973) The Commission on Money and Credit: An Adventure in PolicyMaking, Englewood Cliffs, NJ, Prentice-Hall.

Schwartz, A. (1992) 'The Misuse of the Fed's Discount Window', Federal Reserve Bank of St. Louis Review, 59-69.

Silver Prices and the Adequacy of Federal Actions in the Marketplace, 1979-80: Hearings before a Subcommittee of the Committee on Government Operations, House of Representatives, 96th Congr., 2nd session (1980).

Star, S. L. and Griesemer, J. (1989) 'Institutional Ecology, 'Translations' and Boundary Objects: Amateurs and Professionals in Berkeley's Museum of Vertebrate Zoology, 1907-39', Social Studies of Science, 19, 387-420.

Stevens, E. (1984) 'Risk in Large-Dollar Transfer Systems', Economic Review of Federal Reserve Bank of Cleveland, 83, 1-16.

Stiglitz, J. (2010) Freefall: America, Free Markets, and the Sinking of the World Economy, New York, W. W. Norton \& Company.

Willis, P. B. (1970) The Federal Funds Market: Its Origin and Development, Boston, Federal Reserve Bank of Boston.

Wojnilower, A. (1980) 'The Central Role of Credit Crunches in Recent Financial History', Brookings Papers on Economic Activity, 1980, 277-339.

Wynne, B. (1992) 'Uncertainty and Environmental Learning', Global Environmental Change, 2, 111-127. 